\title{
Publisher Correction: Global epidemiology of systemic lupus erythematosus
}

Megan R. W. Barber(D, Cristina Drenkard(D, Titilola Falasinnu, Alberta Hoi (D), Anselm Mak (D), Nien Yee Kow (D), Elisabet Svenungsson (D), Jonna Peterson (D), Ann E. Clarke (iD) and Rosalind Ramsey-Goldman (D)

Correction to: Nature Reviews Rheumatology https://doi.org/10.1038/s41584-021-00668-1, published online 03 August 2021.

The originally published article contained errors in Figs. 1 and 2, in which India was not shown. These figures have been corrected in the HTML and PDF versions of the article to reflect that recent data on the estimated incidence and prevalence of systemic lupus erythematosus in India are not available.

https://doi.org/10.1038/s41584-021-00690-3 I Published online 1 September 2021

(C) Springer Nature Limited 2021 